\title{
HUBUNGAN TEKANAN MENYIKAT GIGI DENGAN TERJADINYA GIGI SENSITIF PADA MASYARAKAT DESA KANDANG KECAMATAN DARUL IMARAH KABUPATEN ACEH BESAR TAHUN 2018
}

\author{
Andriani*, Elfi Zahara \\ Jurusan Keperawatan Gigi Poltekkes Kemenkes Aceh \\ J1. Soekarno Hatta Desa Lagang Kecamatan Darul Imarah Kabupaten Aceh Besar \\ *Korespondensi penulis: andriani.muslimyes@gmail.com
}

\begin{abstract}
ABSTRAK
Latar Belakang: Gigi sensitif terjadi karena ada penipisan pada lapisan email sehingga lapisan dentin di bawahnya menjadi terbuka. Penelitian ini bertujuaan untuk mengetahui hubungan tekanan yang besar atau berlebih saat menyikat gigi dengan terjadinya gigi sensitif pada masyarakat Desa Kandang Kecamatan Darul Imrah Kabupaten Aceh Besar Tahun 2018.

Metode: Penelitian ini bersifat analitik, dengan pendekatan cross sectional Populasi penelitian adalah seluruh masyarakat yang menggunakan gigi tiruan sebagian lepasan 35 orang, sampel dalam penelitian ini berjumlah 35 orang responden. pengumpulan data yang dilakukan melalui wawancara dengan menggunakan kuesioner.

Hasil: Hasil penelitian menunjukkan bahwa dari 89 masyarakat desa kandang yang menggunakan tekanan pada saat menyikat gigi terlihat adanya gigi sensitif sebanyak $60,7 \%(p=0,026)$.

Kesimpulan: Ada hubungan antara tekanan pada saat menyikat gigi dengan gigi sensitve $(p<0,05)$. dan disarankan kepada seluruh masyarakat yang mengalami gigi sensitif agar mampu menjaga dan memelihara kesehatan gigi dan mulutnya
\end{abstract}

Kata Kunci: tekanan menyikat gigi; gigi sensitif

\section{ABSTRACT}

\section{THE RELATIONSHIP OF TOOTH-BRUSHING PRESSURE \\ WITH SENSITIVE TEETH IN KANDANG VILLAGE, KECAMATAN DARUL IMARAH DISTRICT OF ACEH BESAR}

Background: Sensitive teeth occur because there is thinning in the enamel layer so that the dentin layer below becomes exposed. This study aims to find out the relationship of toothbrushing pressure with the occurrence of sensitive teeth in Kandang Village, Kecamatan Darul Imrah, District of Aceh Besar in 2018.

Methods: This study was analytical with a cross sectional approach. The population in this study were all communities in Kandang Village, a sample of 89 people taken based on simple random techniques. Data were obtained by interviewing using a questionnaire.

Results: The results showed that of the 89 cage villagers who used pressure when brushing their teeth there were $60.7 \%$ sensitive teeth $(p=0.026)$.

Conclusion: It can be concluded that there is a relationship between pressure when brushing teeth with sensitive teeth $(p<0.05)$. and recommended to all people who experience sensitive teeth to be able to maintain and maintain the health of their teeth and mouth.

Keyword: tooth-brushing pressure; sensitive teeth 


\section{PENDAHULUAN}

Gigi memiliki fungsi yang penting untuk mengunyah, berbicara dan mempertahankan bentuk muka, sehingga menjaga kesehatan gigi dan mulut merupakan komponen esensial dari kesehatan tubuh secara keseluruhan. ${ }^{1}$

Gigi sensitif merupakan istilah yang sering digunakan masyarakat umum untuk menunjukkan kondisi dentine hypersensitive, yaitu terbukanya tubuli dentin akibat menipisnya lapisan email. ${ }^{2}$ Penderita gigi sensitif akan mengalami rasa sakit yang pendek dan tajam secara tiba-tiba ketika dentin yang terpapar mendapat rangsangan. ${ }^{3}$ Rangsangan dapat berupa panas atau dingin, taktil atau sentuhan, uap dan rangsangan kimiawi. ${ }^{4}$ Dentin yang terbuka dapat terjadi akibat atrisi, abrasi dan erosi gigi. Penyikatan gigi yang terlalu kuat dengan bulu sikat yang keras dapat mengakibatkan resesi gingiva di bagian bukal gigi posterior. $^{3}$

Rasa ngilu pada gigi sensitif dapat terjadi ketika dentin terbuka akibat hilangnya lapisan email di atasnya, atau ketika hilangnya jaringan gingiva yang menutupi akar gigi (resesi gingiva) yang membuat tubuli dentin terpapar lingkungan rongga mulut. ${ }^{5}$ Sehingga ketika mendapatkan stimuli seperti dingin dapat menyebabkan pergerakan cairan di dalam tubuli dentin serta mengkatifkan reseptor mekanis pada dinding pulpa. ${ }^{5}$ Walaupun rasa sakit yang timbul hanya dalam jangka waktu pendek, namun dapat membuat ketidaknyamanan saat makan serta mempengaruhi kesehatan rongga mulut jika tidak dirawat. Rasa sakit yang terjadi pada hipersensitif dentin akan mempengaruhi fungsi rongga mulut dan bila tidak dirawat maka akan menimbulkan defisiensi nutrisi pada penderita. ${ }^{2}$

Data IPSOS Indonesia 2011 menunjukkan bahwa sebanyak $45 \%$ orang di Indonesia merasakan nyeri karena gigi sensitif saat mengkonsumsi makanan atau minuman dingin, panas, atau asam dan 52\% orang Indonesia tidak menyadari bahwa mereka memiliki gigi sensitif tanpa memeriksakannya ke dokter gigi. $^{2}$

Hipersensitif dentin merupakan masalah yang cukup sering terjadi, menurut beberapa laporan, dan menunjukkan bahwa secara umum hal ini terjadi pada 1 sampai $74 \%$ masyarakat (di seluruh dunia). ${ }^{5}$ Banyak orang menderita gigi sensitif dan keluhan ini dapat di timbulkan kapan saja. Namun kasus ini lebih sering di jumpai pada usia akhir dekade ke tiga hidup, meskipun kasus ini juga dijumpai pada mereka yang berusia remaja. ${ }^{2}$ Keluhan gigi sensitif juga lebih banyak di jumpai pada wanita dari pada pria. Jenis minuman bersoda, makan dan minum panas dingin dalam waktu hampir bersamaan dapat memicu terjadinya rasa ngilu pada gigi yang lazim disebut gigi sensitif. ${ }^{3}$

Gigi sensitif secara tidak langsung akan menimbulkan masalah lain, seperti terganggunya pembersihan gigi dan mulut yang akhirnya akan menyebabkan kelainan lebih lanjut maka gigi sensitif perlu dirawat maka penting melihat faktor-faktor apa saja yang menjadi penyebab gigi sensitif ini sehingga dapat mencegah keparahan gigi sensitif yang lebih lanjut. ${ }^{4}$

Berdasarkan hasil survey yang dilakukan di sebuah Puskesmas di Aceh Besar tahun 2011 menunjukkan bahwa $49,5 \%$ masyarakat mengetahui mengenai gigi sensitif.2 Biasanya mereka hanya membiarkan tanpa penanganan serius karena dianggap masalah yang wajar dan hanya terjadi musiman. Mereka mengobatinya tanpa berkonsultasi ke dokter gigi, bahkan $50 \%$ penderita tetap tidak tertangani untuk problem ini. ${ }^{4}$

Upaya kesehatan gigi perlu ditinjau dari aspek lingkungan, pengetahuan, pendidikan, kesadaran masyarakat dan penanganan kesehatan gigi termasuk pencegahan dan perawatan. Namun sebagian besar orang masih mengabaikan kondisi kesehatan gigi secara keseluruhan. Perawatan gigi dianggap tidak terlalu penting, padahal manfaatnya sangat vital dalam menunjang kesehatan dan penampilan. ${ }^{7}$

Mulut bukan sekedar untuk pintu masuknya makanan dan minuman, tetapi fungsi mulut lebih dari itu dan tidak banyak orang mengetahui. Mulut merupakan bagian yang penting dari tubuh kita dan dapat dikatakan bahwa mulut adalah cermin dari kesehatan gigi karena banyak penyakit umum.7

Data terbaru kesehatan RI dari hasil riset kesehatan dan prevalensi penduduk Indonesia memiliki gigi sensitif sebanyak $65 \%$ masyarakat Indonesia memiliki gigi sensitif dan setengahya tidak melakukan tindakan apapun untuk mengulanggi masalah ini. Terlebih lagi didapatkan hanya $6 \%$ telah menggunakan pasta gigi khusus untuk gigi sensitif dan 19\% yang sudah memeriksakan diri kedokter gigi mayoritas $65 \%$ penderita gigi sensitif berusia 20-50 tahun atau berada dalam usia produktif. ${ }^{8}$ Data WHO juga menyebutkan bahwa 50 persen penduduk Indonesia mengalami masalah gigi sensitif bahkan tanpa mereka sadari kondisi ini tentunya mempengaruhi kualitas hidup jika dikaitkan dengan gangguan produktivitas seharihari. ${ }^{9}$

Berdasarkan hasil wawancara awal yang dilakukan pada 15 orang masyarakat Desa Kandang Kecamatan Darul Imarah Kabupaten 
Aceh Besar tahun 2018, didapatkan data masyarakat yang mengalami gigi sensitif, dengan keluhan giginya terasa ngilu pada saat mengkonsumsi makanan dan minuman yang dingin, juga pada saat makan makanan yang manis dan asam. Dari data tersebut penulis tertarik untuk mengadakan penelitian tentang hubunggan tekanan menyikat gigi dengan terjadinya gigi sensitif pada masyarakat Desa Kandang Kecamatan Darul Imarah Kabupaten Aceh Besar tahun 2018.

\section{METODE}

Penelitian ini bersifat analitik dengan pendekatan cross sectional. Populasi dalam penelitian ini adalah seluruh masyarakat di Desa Kandang Kecamatan Darul Imarah Kabupaten Aceh Besar sedangkan sampel pada penelitian ini berjumlah 89 orang dan diambil berdasarkan teknik acak sederhana. Variabel independen (pengaruh) yaitu tekanan menyikat gigi yang besar atau berlebih, sedangkan variabel dependen (terpengaruh) yaitu gigi sensitif.

Pengumpulan data dengan melakukan pemeriksaan ada tidaknya gigi sensitif dan wawancara. Instrumen yang digunakan dalam penelitian ini adalah kuesioner, kartu status pasien dan diagnosa set. Analisis data pada penelitian ini menggunakan uji statistik dengan uji chi square. Analisis Univariat bertujuan untuk mengetahui distribusi ferkuensi masing masing variabel. Analisis bivariat bertujuan untuk mengetahui hubungan antara variabel independen yaitu tekanan yang besar atau berlebih menyikat gigi dengan variabel dependen yaitu Gigi sensitif. Analisis data menggunakan Statistik Program for Social Scince (SPSS), dengan pengujian hipotesis chi square dengan taraf signifikan $p<0,05$.

\section{HASIL DAN PEMBAHASAN}

Hasil penelitian mengenai hubungan tekanan menyikat gigi dengan gigi sensitif masyarakat desa Kandang Kecamatan Darul Imarah Aceh Besar dapat dilihat pada tabel 1.

Berdasarkan hasil penelitian pada 89 masyarakat Desa Kandang, 54 orang $(60,7 \%)$ responden yang menggunakan tekanan menyikat gigi, memiliki gigi sensitif sebanyak 40 orang $(74,1 \%)$ sementara pada 14 orang $(25 \%)$ tidak ada gigi sensitif. Pada 35 orang (39\%) responden yang tidak melakukan tekanan menyikat gigi, 17 orang $(48,6 \%)$ terlihat ada gigi sensitif dan 18 orang $(51,4 \%)$ tidak ada gigi sensitif.
Berdasarkan hasil uji statistik menunjukkan bahwa ada hubungan antara tekanan menyikat gigi dengan gigi sensitif dengan $p=0.026$ ( $p<$ $0,05)$.

Tabel 1. Hubungan Tekanan Menyikat gigi dengan Gigi sensitif masyarakat desa Kandang Kecamatan Darul Imarah Aceh Besar

\begin{tabular}{|c|c|c|c|c|c|c|c|}
\hline \multirow{3}{*}{$\begin{array}{l}\text { Tekanan } \\
\text { Menyikat } \\
\text { Gigi }\end{array}$} & \multicolumn{4}{|c|}{ Gigi Sensitif } & \multirow{3}{*}{ Total } & \multirow{3}{*}{$\%$} & \multirow{3}{*}{$p$ value } \\
\hline & \multicolumn{2}{|c|}{ Ada } & \multicolumn{2}{|c|}{ Tidak Ada } & & & \\
\hline & $\mathbf{n}$ & $\%$ & $\mathbf{n}$ & $\%$ & & & \\
\hline Ada & 40 & 74,1 & 14 & 25,9 & 54 & 100 & \\
\hline Tidak Ada & 17 & 48,6 & 18 & 51,4 & 35 & 100 & 0,026 \\
\hline Total & 57 & 64,0 & 32 & 36,0 & 89 & 100 & \\
\hline
\end{tabular}

Penulis berasumsi bahwa tekanan menyikat gigi pada masyarakat berperan penting terhadap terjadinya gigi sensitif pada masyarakat .Gigi sensitif pada masyarakat tersebut dapat terjadi apabila tekanan menyikat gigi tidak terjaga termasuk dalam kriteria tidak ada maka masyarakat terhindar dari gigi sensitif sehingga masyarakat tersebut kebayakan keseringgan menyikat gigi dengan tekanan yang kuat.

Menurut Depkes RI, cara menggosok gigi yang baik dimulai pada permukaan labial, sikat gigi digerakkan dengan gerakan maju mundur yang pendek yaitu sikat gigi digerak-gerakkan ditempat serta menggosok terlebih dahulu gigigigi yang terletak di belakang. Sesudah itu, barulah menggosok gigi depan. Pada gigi permukaan dekat lidah, gigi-gigi yang terletak di belakang digosok terlebih dahulu, kemudian dilanjutkan bagian depan. Pada permukaan dataran pengunyahan dari gigi, rahang atas maupun rahang bawah digosok dengan gerakan maju mundur. Cara yang dianjurkan adalah dengan dilakukan berulang-ulang pada satu tempat dahulu baru pindah ke tempat lain. ${ }^{10}$

Penyikatan gigi bertujuan (1) untuk menghilangkan plak dan mencegahnya terbentuk kembali; (2) membersihkan gigi dari sisa makanan, debris dan stain; (3) menstimulasi jaringan gusi serta; (4) mendapatkan mafaat dari pasta gigi dengan kandungan khusus untuk mencegah karies, penyakit periodontal maupun mengurangi sensitivitas dentin. ${ }^{11}$

Menyikat gigi merupakan suatu usaha yang efektif untuk menghilangkan debris dan plak gigi. ${ }^{12}$ Namun kebiasaan menggosok gigi dengan tekanan berlebihan dapat membuat gusi mengalami iritasi dan resesi gingiva, lapisan email pun akan berkurang keterbalannya sehingga dentin terbuka dan menjadi lebih peka 
bila mendapat rangsangan saat minum air dingin, asam/ manis atau bahkan tersentuh bulu sikat. ${ }^{3}$

Hal yang perlu diperhatikan dalam menggosok gigi adalah waktu menggosok gigi. Menggosok gigi minimal dilakukan dua kali dalam sehari, yaitu pagi hari setelah sarapan dan malam hari sebelum tidur. Hal ini disebabkan karena dalam waktu 4 jam, bakteri mulai bercampur dengan makanan dan membentuk plak gigi. Menyikat gigi setelah makan bertujuan untuk menghambat proses tersebut. Lebih baik lagi menambah waktu menyikat gigi setelah makan siang atau minimal berkumur air putih setiap habis makan. ${ }^{13}$

Efek abrasif penyikatan gigi yang dapat menimbulkan gigi sensitif tergantung pada arah dan frekuensi gerakan penyikatan, jenis bulu sikat serta tekanan menyikat gigi. ${ }^{14}$ Menggosok gigi dilakukan dengan lembut. Menyikat gigi yang terlalu keras dapat menyebabkan kerusakan gigi dan gusi. Menggosok gigi tidak diperlukan tekanan yang kuat karena plak memiliki konsistensi yang lunak, dengan tekanan yang ringan plak akan terbuang. ${ }^{13}$

Menggosok gigi yang terlalu cepat tidak akan efektif membersihkan plak. Menggosok gigi yang tepat dibutuhkan durasi minimal 2 menit. Sikat gigi yang sudah berusia 3 bulan sebaiknya diganti karena sikat gigi tersebut akan kehilangan kemampuannya untuk membersihkan gigi dengan baik. Apabila kerusakan sikat gigi terjadi sebelum berusia 3 bulan merupakan tanda bahwa saat menggosok gigi tekanannya terlalu kuat. Selain itu perlu dijaga pula kebersihan sikat gigi karena sikat gigi adalah salah satu sumber menempelnya kuman penyakit. ${ }^{6}$

\section{KESIMPULAN}

Setelah dilakukan penelitian dapat disimpulkan bahwa ada hubungan antara tekanan menyikat gigi dengan gigi sensitif pada masyarakat Desa Kandang Kecamatan Darul Imarah Kabupaten Aceh Besar.

Berdasarkan hasil penelitian ini, disarankan pada masyarakat untuk dapat menyikat gigi dengan cara yang baik dan benar, menghilangkan kebiasaan menggosok gigi terlalu keras yang dapat menyebabkan gigi menjadi sensitif, serta perlu dilakukan pemeriksaan dan perawatan gigi sensitif oleh petugas kesehatan gigi maupun memeriksakan kesehatan gigi mulut secara 6 bulan sekali.

\section{DAFTAR PUSTAKA}

1. Glick M, Williams DM, Kleinman DV, Vujicic M, Watt RG, Weyant RJ. A new definition for oral health developed by the FDI World Dental Federation opens the door to a universal definition of oral health. British dental journal. 2016 Dec; 221(12):792.

2. Ray N, Bany ZU, Rezeki S. Gambaran Pengetahuan Pasien Mengenai Gigi Sensitif Di Puskesmas Baitussalam Aceh Besar. Journal Caninus Dentistry. 2017 Oct 27;2(4):162-8

3. Trushkowsky RD, Garcia-Godoy F. Dentin hypersensitivity: differential diagnosis, tests, and etiology. Compend. Contin. Educ. Dent. 2014 Feb;35(2):99-104.

4. Maria, Melisa. Sensodyne Expert Sharing Tanya Pensodent. 2010. http//.Kesehatan kompas com [diakses 10 Oktober 2019]

5. Gillam DG. Management of dentin hypersensitivity. Current Oral Health Reports. 2015 Jun 1;2(2):87-94.

6. Pratiwi, D. Gigi Sehat Merawat Gigi Sehari - hari Jakarta: PT Kompas Media Nusantara. 2007

7. Kusumawardani, Endah. Buruknya Kesehatan Gigi dan Mulut. Yogyakarta: Penerbit Siklus. 2011

8. Be'kien Nio. Preventive Dentisry. Jakarta: EGC. 1995

9. Rahmadhan, Ardyan Gilang. Serba Serbi Kesehatan Gigi dan Mulut. Jakarta: Bukun. 2010

10. Depertemen Kesehatan RI. Cara Menyikat Gigi. Jakarta. 1996

11. Baruah K, Thumpala VK, Khetani P, Baruah Q, Tiwari RV, Dixit H. A review on toothbrushes and tooth brushing methods. International Journal of Pharmaceutical Science Invention. 2017 May;6(5):29-38.

12. Liana I, Arbi A. Hubungan Tindakan Menggosok Gigi Dengan Status Kebersihan Gigi Dan Mulut Pada Murid Kelas V Dan VI Sekolah Dasar di Peudada Kabupaten Bireuen. Jurnal Bahana Kesehatan Masyarakat (Bahana of Journal Public Health). 2019 Jun 7;3(1):26-9.

13. Sitanaya RI. Pengaruh teknik menyikat gigi terhadap terjadinya abrasi pada servikal gigi Media Kesehatan Gigi: Politeknik Kesehatan Makassar. 2017 Jul 30;16(1).

14. Bizhang M, Schmidt I, Chun YH, Arnold WH, Zimmer S. Toothbrush abrasivity in a long-term simulation on human dentin depends on brushing mode and bristle arrangement. PloS one. 2017;12(2) 